\title{
CIVIL AND MILITARY AVIATION EDUCATION AS INTERDISCIPLINARY DIDACTIC SYSTEM: UPDATED KNOWLEDGE, SKILLS AND COMPETENCES

\author{
Zuzana Zgodavová ${ }^{1}$, Daniela Čekanová ${ }^{2}$, Stanislav Szabo jr. ${ }^{3}$, \\ Marek Košuda ${ }^{4}$, Stanislav Szabo
}

\begin{abstract}
On the basis of a national analysis and the expert discussion, this article presents a methodological approach to the realization of professional education and the creation of the required competencies for civilian and military aviation personnel, based on a system approach platform, with the application in the specific aviation education environment of future employees in the Transport sector. This article presents the third part of a study. The article used analysis and synthesis tools, the method "per partes" (integration in parts) and an expert method. The authors solved the following praxeological questions: How to identify the Interdisciplinary Didactic System for creating the required competencies of aviation personnel in the conditions of the Slovak Republic? What are the core themes of aviation knowledge in the Transport sector, the skills and competencies of our graduates? The strategic framework for the solutions is the implementation of a state education policy, the transport policy, the defence policy of the state and the relevant international and the European agenda, in the conditions of universities in Slovakia, in cooperation with their partners. The core outputs of this article are the framework knowledge, the skills and competences of graduates identified in the new field of study "Transport" in the Slovak Republic.
\end{abstract}

UDC Classification: 378, DOI: 10.12955/cbup.v7.1439

Keywords: education, knowledge alliance, aviation, didactic system

\section{Introduction}

The process of creating a new system and descriptions of new study fields of the Slovak Republic-with a logical link to former fields of study which were identified and created by the guarantors in 2003 and similar, is now being finalized. The new intentions are integrated into one specific field of study. However, their uniqueness cannot be affected (Ministry of Education 2018). Not the present situation, but the need for aviation personnel in the future forces us to take the responsibility for this task. The challenges of social life with a view to 2030, as well as the technical and technology development in the spirit of the 21 st Century Industry (Industry 4.0 etc.), the Digital Agenda for Europe, etc., also determine the development of the agenda of the field of study "Transport". The joint aviation education of civilian and military aviation personnel is being organized again in the Slovak Republic from the academic year 2016/2017. The executives are the eligible public and private entities that make up the Knowledge Alliance of Aviation Education, which is actively involved in creating a professional description of the new integrated field of study "Transport" in the Slovak Republic.

Our work on the solving this issue must reflect the current educational knowledge and scientific research results and horizons. Our activities will be partly focused on the theoretical elaboration of the draft description on the two levels: the transport for the 21st Century; the aviation education as the interdisciplinary didactic system, within the framework of the state educational policy for the $21 \mathrm{st}$ century will be expressed in the description of new proposal of the field of study "Transport".

In order to ensure the continuity, quality and safety in the aviation education of future military and civil aviation professionals, research works, especially a doctoral thesis, of a similar nature are needed.

The main objective of this article is to create a proposal for the new interdisciplinary didactic system and the main themes of the knowledge and skills for creating the required competencies of aviation personnel in the conditions of the Slovak Republic.

We have the following praxeological questions: How to identify the Interdisciplinary Didactic System for creating the required competencies of aviation personnel in the conditions of the Slovak Republic. What are the core themes of aviation knowledge in the Transport sector, the skills and competencies of our graduates?

Our assumption is that for the needs of a state such as the Slovak Republic for the continuous aviation and training of professionals the optimal solution is the realization of state-private cooperation and partnership as a service of the knowledge alliance of aviation education.

\footnotetext{
${ }^{1}$ Technical University of Košice, Faculty of Aeronautics, Košice, Slovakia, zuzana.zgodavova@tuke.sk

${ }^{2}$ Technical University of Košice, Faculty of Aeronautics, Košice, Slovakia, daniela.cekanova@tuke.sk

${ }^{3}$ Technical University of Košice, Faculty of Aeronautics, Košice, Slovakia, stanislav.szabo.2@tuke.sk

${ }^{4}$ Technical University of Košice, Faculty of Aeronautics, Košice, Slovakia, marek.kosuda@tuke.sk

${ }^{5}$ Technical University of Košice, Faculty of Aeronautics, Košice, Slovakia, stanislav.szabo@tuke.sk
} 
The updated content of education respects a new description of the field of stuy "Transport" was led by the Dean of the Faculty of Aeronautics, Assoc. Prof. Stanislav Szabo.

\section{Literature review: Researching the theoretical frameworks of the Knowledge Alliance for the description of the new integrated field of study, Transport}

Aviation education has a much wider meaning than just the education and training of pilots.

The core elements of education and training as the part of the Knowledge Alliance of Aviation Education and as the State-Privat education service are presented in Table 1.

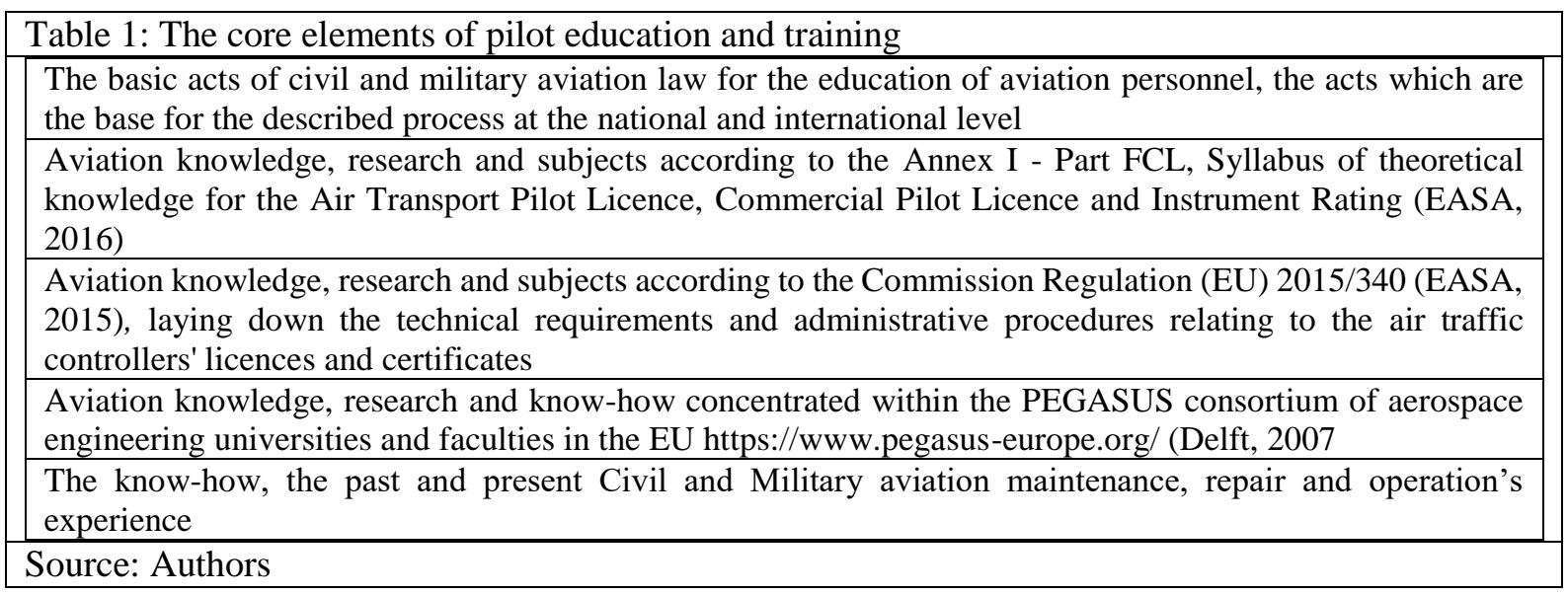

The results of the theoretical work and the scientific and research activities in the field of: University Academic subjects, Social and Human Sciences, the Simulation and modelling of Security issues, the Applied Technical Sciences, the Applied Civil and Military / Air Force management, education and training etc. within the Expert Database of Civil and Military Aviation Experience in progess.

The selected theoretical frameworks of the Knowledge Alliance within the Simulation and modelling of Security issues are within the work by Fuchs et al. (2010) focused on the simulation of dangerous substances outflows into the environment because of traffic accidents by dangerous substances transport; in the study by Dvorak et al. (2010) on the enhancing of security on critical accident locations using telematics support; in the work by Balatka et al. (2011) on the exposure of the environment and surface water by dangerous liquid - the slop outflow model; in the study by Kelemen and Blištanová (2014) on the applied knowledge in the logistic modelling to handle the threat of floods with aviation logistic support; in the study by Kompis et al. (2011) on the parallel computational models for composites reinforced by CNT-fibres for personal and vehicle protection materials; in the work by Vágner and Papová 2014) on the comparison of Radar Simulator for Air Traffic Control used also for the education of new Air Traffic Controllers; in the work by Pavolová and Tobisová (2013) on the model of supplier quality management in the transport company applied for air transport; in the study by Kuzma et al. (2016) on the use of the CAX System as a tool for modeling construction elements in the aviation industry; or in the work by Fözö et al. (2009) on the advanced anytime control algorithms and the modeling of turbojet engines etc.

The selected theoretical frameworks of the Knowledge Alliance within the Applied Technical Sciences are within the work by Nečas and Kelemen (2009) on the call for more security in the technology revolution: in the work by Bučka and Kelemen (2009) on the analysis of the specific requirements related to the Slovak Air Force; in the book by Hovanec (2016) on the digital factory as a prerequisite for successful application in the area of ergonomics and the human factor; in the study by Andoga et al. (2018) on the intelligent situational control of small turbojet engines; in the work by Draganova et al. (2017) on the non-stationary noise analysis of magnetic sensors using allan variance; in the study by Semrad et al. (2014) on the analysis of all composite wing design containing magnetic microwires; or in the works by Polishchuk et a. (2019) on the evaluation of start-ups projects etc.

The selected theoretical frameworks of the Knowledge Alliance within the Applied Civil and Military / Air Force management, education and training are within the work by Socha et al. (2016) on the training of pilots using a flight simulator and its impact on the piloting precision; in the study by Rozenberg et al. (2016) on the critical elements in piloting techniques in aerobatic teams; in the work by Durco et al. 
(2017) on the means of using CPDLC with ATC procedures in a terminal maneuvering area; in the study by Nečas et al. (2009) on information operations and media: Beyond the Security Scope; in the analysis by Kalavsky et al. (2015) on the conditions for the abandonment of a helicopter using a personal rescue parachute; in the work by Sopoci et al. (2009) on the Air Force knowledge within the Military Management in the 21 century and the Transformation of Army etc.

\section{Identification of the problem and the methodology}

The main problem is a proposal of the new interdisciplinary didactic system and the main themes of the knowledge and skills for creating the required competencies of aviation personnel in the conditions of the Slovak Republic.

When analyzing the phenomenon, we used the tools of analysis and synthesis, with the method "per partes" (integration in parts) in the aviation practice.

The historical analysis of the aviation didactic systems was carried out on the data basis of the selected institutions from 1959 until the present in the Table 2.

\begin{tabular}{|c|}
\hline \\
\hline Vojenské letecké účilište Košice (Military aviation school in Košice, Slovakia) \\
\hline Vojenská stredná škola letectva v Košiciach (Military Hight School in Košice, Slovakia) \\
\hline Odborná výcviková škola letectva Košice (Professional Training School of Air Force Košice, Slovakia) \\
\hline $\begin{array}{l}\text { Vysoká vojenská letecká škola SNP v Košiciach (Military Aviation College of Slovak National } \\
\text { Uprising in Košice, Slovakia) }\end{array}$ \\
\hline $\begin{array}{l}\text { Vojenská letecká akadémia gen. Milana Rastislava Štefánika v Košiciach (Air Force Academy of Gen. } \\
\text { M. R. Šefánik in Košice, Slovakia) }\end{array}$ \\
\hline $\begin{array}{l}\text { Letecká fakulta Technickej univerzity v Košiciach (Faculty of Aeronautics, the Tehchnical University } \\
\text { of Košice, Slovakia) }\end{array}$ \\
\hline Lotnicza Akademia Wojskowa - "Szkoła Orląt" (Air Force Academy in Deblin, Poland) \\
\hline $\begin{array}{l}\text { Univerzita obrany, Fakulta vojenských technológií, the Czech Republic (University of Defeence, } \\
\text { Faculty of Military Technology, teh Czech Republic) }\end{array}$ \\
\hline École de l'air, Salon-de-Provence, France (French Air Force Academy) \\
\hline Source: Authors \\
\hline
\end{tabular}

The lessons learned from the historical analysis were compared with the findings gained by the expert method. The expert group consisted of 5 specialists experienced in aviation education and training. The data was obtained through interviews with the experts.

This article represents the area of pedagogical research in the study and scientific field "Transport" in the Air Transport subgroup. Data collection for the study of the issue was carried out during 2018/2019. The origin of the analyzed material is in the database of 60 years of aviation education within Czechoslovakia and the Slovak Republic. Our national experience, including personal experience, has been compared and complemented by the successful experience of aeronautical training abroad (Czech Republic, Poland, France). From 2018 the Faculty of Aeronautics of the Technical University in Košice is a part of this international educational consortium based in Košice. These new findings have affected the results presented in the article.

\section{Results and Discussion}

The description of the field of study is intended to provide a framework for the creation and achievement of the planned knowledge, skills and competences of graduates at different levels of university education, in accredited study programs in the newly integrated field of study Transport.

An effective tool for the building and developing the required competencies of the personnel in the selected transport area, with emphasis on the Air Transport/Aerospace Engineering, is AVIATION EDUCATION, including the aeronautical science education, upbringing and training.

The central notion is EDUCATION as a set of educational activities and conditions that have an improving intention and effect in a holistic upbringing of man.

The process of education, using the knowledge of general didactics, helps develop personality within cognitive, social and perceptual-motor teaching (learning) (Petlák, 2004; Turek, 2004). The required education, upbringing and the level of training is the result which, in accordance with the psychophysiological features of individuals, create their COMPETENCIES for a certain activity. 
The authorised state, public and private entities are the implementers who create the Knowledge Alliance of Aviation Education, on the platform in Table 3.

\begin{tabular}{|l|}
\hline \multicolumn{2}{|l|}{ Table 3: The Knowledge Alliance of Aviation Education } \\
\hline State and Public entities of the Knowledge Alliance \\
\hline Technical University of Kosice, Faculty of Aeronautics, Slovakia \\
\hline $\begin{array}{l}\text { The contracting partner, Armed Forces Academy of General Milan Rastislav Stefanik in Liptovsky } \\
\text { Mikulas / Ministry of Defence of the Slovak Republic }\end{array}$ \\
\hline The Air Force of the Armed Forces of the Slovak Republic / Armed Forces of the Slovak Republic \\
\hline University of Zilina, Faculty of Business, Economics, Transport and Communications, Slovakia \\
\hline Selected aircraft maintenance training organizations \\
\hline Air traffic services of the Slovak Republic, Ltd. Bratislava \\
\hline Private entities of the Knowledge Alliance \\
\hline $\begin{array}{l}\text { Slovak Training Academy, Ltd. - a contractor for practical flight training of helicopter pilots / at } \\
\text { present foreign pilots }\end{array}$ \\
\hline AirJob, Ltd., JetAge, Ltd. - contractual partners for the practical flight training of airplane pilots \\
\hline Selected aircraft maintenance training organizations \\
\hline Source: Authors \\
\hline
\end{tabular}

Main themes of the knowledge core of the field of study "Transport"

The main themes of the field of study respect the type of transport and also contain the theoretical foundations of the university study. The main themes of the knowledge core are: mathematical and physical fundamentals (mathematics, physics, informatics, theory of mass operation, operational and system analysis), electrical engineering, electronics, engineering, legislation and legal standards, transport safety and human factor in systems and processes; (economics of transport enterprises and processes, business and financial management, management, marketing, accounting); transport technology; transport means and systems (materials, control and instrumentation systems, sensors, navigation, maintenance, drives, etc.) (transport infrastructure, construction of transport, non-flammable and space means, transport flow theory, transport integration, intelligent transport and robotic systems), foreign languages, logistics (forwarding, transport and mail services, material handling, multimodal transport), modelling and simulation (CAX technology, modelling and simulation of electrical and electronic systems and circuits, process optimization, economic efficiency, quality, impact on the environment); navigation; selected systems and processes. Furthermore, they are bound to the theoretical principles of the individual theoretical disciplines (solid state and fluid mechanics, statistics, dynamics, cybernetics, selected electronic and / or electro-technical and / or engineering disciplines, understanding the activities of transport means in the context of ethical and environmental aspects in the field of study at both the national and international levels).

Knowledge, skills and competences of the graduate of the 1st degree study program in accordance with the relevant level of the national qualification framework

The graduates have interdisciplinary knowledge in the field of study, Transport, including the basic concepts, patterns and contexts of subjects of a theoretical basis and specific technical subjects for practicing the chosen field of education within the field, expressed in a particular study program of the first degree of university education.

They demonstrate knowledge related to the management and economics of systems and processes in the field of Transport, knowledge of modern technical means, controls the principles and functions of their activities, the conditions of their operation and maintenance, the security of systems and processes. On the basis of acquired knowledge, they demonstrate the ability to use them appropriately. They have professional communication skills and can organize teamwork.

The graduates are able to solve problems independently and to make managerial and technical decisions in the field of Transport at primary and secondary functions at home and abroad. They have the ability to professionally present their own opinions, even in a foreign language.

Knowledge, skills and competences of the graduates of the 2nd Grade Study Program in accordance with the relevant level of the National Qualifications Framework

The graduates have extensive professional and methodological knowledge from several areas of university education integrated in the field of study, Transport. They have an interdisciplinary 
knowledge related to the applications of technical, operational and economic knowledge in the field, which are expressed in the study program of the second degree of university education.

They have knowledge of special diagnostic, land/water / air and space/logistics/postal, information, communication and other technology and its use in the field of Transport and its related areas of social life. The graduates are able to design, implement and evaluate the solution of problems related to transportation systems and processes. They can formulate recommendations, procedures to solve professional problems, and design and implement projects to solve them.

They have the professional, communication and managerial skills required to perform senior and senior managerial and technical functions at home and abroad. The graduates demonstrate a high degree of autonomy in solving problems and projects in the field of transport. They have innovative thinking and are ready to present professionally the results of their own analysis and study to a professional audience, even in a foreign language.

Knowledge, skills and competencies of the 3rd Grade Graduate Program in accordance with the relevant level of the National Qualifications Framework

The graduates supervise the methods of basic and applied research in the selected area of university education within the field of study Transport, expressed in the study program of the third degree of university education. They have extensive expertise from several areas of university education within the field of study, which serves as a basis for conducting research, and the development and creation of new knowledge in the field.

The graduates are able to formulate new hypotheses and strategies for further research and development of the field of study, Transport. They apply their own findings of a theoretical analysis and comprehensive scientific research to solve specific problems in the field of university education within the field of study. Based on their outcomes and findings, they are able to design, validate and implement new research and work procedures in the field of Transport.

The graduates can work in managerial and technical functions at the strategic level of systems and processes at home and abroad. They can predict, plan, manage, determine the focus of research, and coordinate a team in the field.

\section{Conclusion}

The article meets the main goal of the pedagogical research to create a proposal of the new interdisciplinary didactic system for the required competencies of aviation personnel in the conditions of the Slovak Republic. The core outputs of article are the framework knowledge, the skills and competences of graduates identified in the new field of study "Transport".

The Knowledge Alliance of Aviation Education as the State-Privat education service is eligible for the comprehensive preparation of the aviation professionals.

All past, current and new aviation knowledge will be focused on the perspective International Expert Database of Civil and Military Aviation Experience that is still in progress.

\section{Acknowledgements}

Article was prepared in the framework of the institutional project "Integrated Aviation Education of Civilian and Military Personnel at the Faculty of Aeronautics, the Technical University of Košice, SR", in 2019-2020.

\section{References}

Andoga, R., Fozo, L., Judicak, J., Breda, R., Szabo, S., Rozenberg, R., \& Dzunda, M. (2018). Intelligent Situational Control of Small Turbojet Engines. International journal of Aerospace Engineering, 2018, 1-16. doi:10.1155/2018/8328792

Annex I - Part FCL. Syllabus of theoretical knowledge for the Air Transport Pilot Licence, Commercial Pilot Licence and Instrument Rating, EASA, Brussels, Belgium, 2016. Retrieved from https://www.easa.europa.eu/sites/default/files/dfu/PartFCL.pdf

Balatka, M., Fuchs, P., Kamenicky, J., Sousek, R., \& Kelemen, M. (2011). Exposure of the environment and surface water by dangerous liquid - the slop outflow model. In Sánchez, M. (ed.), 15th World Multi-Conference on Systemics, Cybernetics and Informatics, Proceedings, Volume III, Orlando, Florida, USA, July 19th - July 22nd, 2011, 280-284.

Bučka, P., \& Kelemen, M. (2009). Requirements related to the Slovak Republic's Air Force. In Vintr, Z. (ed..), International conference on Military Technologies, ICMT '09 [electronic source], Brno, Czech Republic, May 5-9, 2009, $282-289$.

Draganová, K., Moucha, V., Volcko, T., \& Semrád, K., (2017). Non-Stationary Noise Analysis of Magnetic Sensors using Allan Variance. Acta Physica Polonica, 131(4), 1126-1128. 
Drotárová, J., Kačíková, D., Kelemen, M., \& Bodor, M. (2016). The possibilities of using blended learning in fire safety education. In CBU international conference proceedings 2016: innovations in science and education: March 23-25, 2016, in Prague, Czech Republic. Vol. 4; eds. Tavleen Sahota, Mary-Anne Jones. ISBN 978-80-88042-05-1. ISSN 1805-997X. p. 283-286.

Dvorak, Z., Cekerevac, Z., Kelemen, M., \& Sousek, R. (2010). Enhancing of security on critical accident locations using telematics support. In Sánchez, M. (ed.), International conference on society and information technologies, ICSIT 2010 proceedings, Orlando, Florida, USA, April 6th-9th, 2010, 414-417.

Durčo, S., Sabo, J., Rozenberg, R., \& Miženková, Ž. (2017). Means of CPDLC using with ATC procedures in terminal maneuvering area. In Hrubý, M. (eds.), Distance Learning, Simulation and Communication 2017, proceedings, Brno, Czech Republic, May 5-9, 2017, 62-67.

EASA, Commission Regulation (EU) 2015/340 of 20 February 2015, Brussels, Belgium, 2015. Retrieved from https://www.easa.europa.eu/document-library/regulations/commission-regulation-eu-2015340

Fuchs, P., Novak, P., Saska, T., Smida, J., Dvorak, Z., Kelemen, M., \& Sousek, R. (2010). Simulation of dangerous substances outflows into the environment because of traffic accidents by dangerous substances transport. In Sánchez, M. (ed.), the 14th world multi-conference on systemics, cybernetics and informatics, WMSCI 2010 proceedings, volume 1, Orlando, Florida, USA, June 29th - July 2nd, 2010, 204-207.

Fözö, L., Andoga, R., \& Madarász, L. (2009). Advanced anytime control algorithms and modeling of turbojet engines. In Rudas, I.J., Fodor, J. \& Kacprzyk, J. (eds.), Computational intelligence and informatics, the 10th international symposium of Hungarian researchers, proceedings, Budapest, Hungary, November 12-14, 2009, 83-94.

Hovanec, M. (2016). Digital factory as a prerequisite for successful application in the area of ergonomics and human factor. Theoretical Issues in Ergonomics Science, 18(1), 35-45.

Kal'avský, P., Socha, V., Socha, L., Kutílek, P., Gazda, J., \& Kimličková, M. (2015). Conditions for Abandonment Out of a Helicopter Using Personal Rescue Parachute. In Stefek, A. \& Krivanek, V. (eds.), International Conference on Military Technologies Location, Book Series: International Conference on Military Technologies, Brno, Czech Republic, MAY 1921, 2015, 467-471.

Kelemen, M., \& Blišt'anová, M. (2014). Logistic Modelling to handle the Threat of Floods - The Bodva River example. In Curran Associates, Inc. (eds.), 14th International Multidisciplinary Scientific GeoConference, SGEM 2014 Conference Proceedings, Volume III, Sofia, Bulgaria, June 17-26, 2014, 715-723.

Kelemen, M. (2017). Security of the Slovak Republic and issues of protected interests: Security and criminal law research topics. In Fire protection, Seafety and Security 2017. International Scientific Conference Proceedings, May 3rd. - 5th., 2017, Zvolen, Slovak Republic. Editors Majlingová, A, Vel'ková, V. Zvolen: Technical university, 2017. ISBN 978-80-2282957-1. 312-316.

Kelemen, M., Nečas, P., \& Terem, P. (2010). Advanced aerospace management of integrated education and training towards comprehensive security. Incas Bulletin, 2 (3/ 2010), 45-49.

Kelemen, M., Nečas, P., Bučka, P., \& Boscoianu, M. (2011). Situational control methods of Aviatic didactic flight safety regulations system. In A ZMNE KLHTK tudományos folyoirata, 4 (1/2011), 18-21.

Kelemen, M., Szabo, S., \& Vajdová, I. (2018). Cybersecurity in the Context of Criminal Law Protection of the State Security and Sectors of Critical Infrastructure. In CNDCGS 2018 International Scientific Conference, 25.04.2018-27.04.2018, Litva. SIGN-TUKE 197361 // Challenges to national defence in contemporary geopolitical situation: proceedings / Bekesiene, S. (editor); Hošková-Mayerová, Šárka (editor). - Vilnius (Litva): The General Jonas Žemaitis Military Academy, 2018. ISSN (online) 2538-8959. 100-104.

Kelemen, M., Szabo, S., \& Vajdová, I. (2018). Security Management in the Air Transport: Example of an Interdisciplinary Investigation of Special Security Questions. In CNDCGS 2018 International Scientific Conference, 25.04.2018-27.04.2018, Litva, Challenges to national defence in contemporary geopolitical situation: proceedings / Bekesiene, S. (editor) ; HoškováMayerová, Šárka (editor). - Vilnius (Litva): The General Jonas Žemaitis Military Academy, 2018. ISSN (online) 2538-8959. 105-108.

Kelemen, M., Pilát, M., Makó, S., Rozenberg, R., \& A. Tobisová (2019). Pricing Policy Aspects in Competitive Fight Between Low-Cost Airlines on Kosice Airport. Journal of Konbin, Vol. 49, 1(2019), 331-342. doi:10.2478/jok-2019-0017

Kompis, V., Qin, QH., Fu, ZJ., Chen, CS., Droppa, P., Kelemen, M., \& Chen, W. Parallel computational models for composites renforced by CNT-fibres. Engineering Analysis with Boundry Elements, Vol. 36, 1/2012, 47-52.

doi:10.1016/j.enganabound.2011.04.009

Kuzma, D., Korba, P., Hovanec, M., \& Dulina, L. (2016). The Use of CAX System as a Tool Modeling Construction Element in the Aviation Industry. Naše more, 63(3) SI, 134-139.

Nečas, P., \& Kelemen, M. (2009). Call for more security: Technology revolution wanted. In in Vintr, Z. (ed.), International conference on Military Technologies, ICMT '09 [electronic source], Brno, Czech Republic, May 5-9, 2009, 246-250.

Nečas, P., Kelemen, M., \& Sopóci, M. (2009). Information operations and media: Beyond the Security Scope? In Stanciu, L. (ed.), $15^{\text {th }}$ International Conference the Knowledge-based Organization: Military Sciences. Security and Defence,

Conference Proceedings 1, Sibiu, Romania, November 26-28, 2009, 96-103.

Pavolová, H., \& Tobisová, A. (2013). The Model of Supplier Quality Management in Transport Company, Naše more, 60 (5/6), 123-126.

Petlák, E. (2004). General Didactics. Bratislava: Martinus. 
Polishchuk, V., \& M. Kelemen. (2019). Information Model of Evaluation and Output Rating of Start-up Projects Development Teams. In Luengo, D. et al. (ed.) Proceedings of the Second International Workshop on Computer Modeling and Intelligent Systems (CMIS-2019), Zaporizhzhia, Ukraine, April 15-19, 2019. CEUR Workshop Proceedings Vol. 2353, CEUR-WS.org 2019, 674-688. Retrieved from http://ceur-ws.org/Vol-2353/paper54.pdf

Polishchuk, V., Kelemen, M., \& Kozuba, J. (2019). Technology Improving Safety of Crowdfunding Platforms Functioning in the Context of the Protection of the Start-Up Investors in the Financial and Transport Sectors. Journal of Konbin, Vol. 49, 1(2019), 313-330. doi:10.2478/jok-2019-0016

PEGASUS consortium of Aerospace Engineering Universities, Delft., Netherlands. Retrieved from https://www.pegasuseurope.org/

Rozenberg, R., Socha, V., Socha, L., Szabo, S., \& Němec, V. (2016). Critical elements in piloting techniques in aerobatic teams. In Ostaševičius, V. (ed.), Transport Means 2016 - Proceedings of the International Conference, Kaunas, Lihuania, October 5-7, 2016, 444-449.

Sample of Field Description. (2008). Bratislava, Slovakia: Ministry of Education, Science, Research and Sport, 2008.

Semrád, K., Lipovský, P., Cernan, J., \& Jurčovič, M. (2014). Analysis of all composite wing design containing magnetic microwires. In Trebuňa, F. (ed.), Modelling of Mechanical and Mechatronic systems, ${ }^{\text {th }}$ Conference on Modelling of Mechanical and Mechatronic systems (MMaMS), Vysoké Tatry, Slovakia, November 25-27, 2014, 428-434.

Socha, V., Socha, L., Szabo, S., Hanak, K., Gazda, J., Kimlickova, M., Vajdova, I., Madoran, A., Hanakova, L., Nemec, V., Puskas, T., Schlenker J., \& Rozenberg, R. (2016). Training of pilots using flight simulator and its impact on piloting precision. In Ostaševičius, V. (ed.), Transport Means 2016, Proceedings of the International Conference, Kaunas, Lihuania, October 5-7, 2016, 374-379.

Sopóci, M., Kelemen, M., \& Nečas, P. (2009). Military Management in 21 century and Transformation of Army. In Stanciu, L. (ed.), $15^{\text {th }}$ International Conference the Knowledge-based Organization: Military Sciences. Security and Defence, Conference Proceedings 1, Sibiu, Romania, November 26-28, 2009, 138-142.

Turek, I. (2004). Innovation in Didactics. Bratislava: MPC, 2004.

Vágner, J., \& Pappová, E. (2014). Comparison of Radar Simulator for Air Traffic Control. Naše more, 61(1-2), 31-35. 